\title{
Yield, Quality and Water Use Efficiencies of Silage Maize as Effected by Deficit Irrigation Treatments
}

\author{
Ali Beyhan Ucak ${ }^{1 *}$, Tugay Ayasan², Nizamettin Turan ${ }^{3}$ \\ ${ }^{1}$ Biosystems Engineering Department, Agricultural Faculty, Siirt University, 56100 Siirt, Turkey \\ ${ }^{2}$ Eastern Mediterranean Agricultural Research Institute, 01321 Adana, Turkey \\ ${ }^{3}$ Field Crops Department, Agricultural Faculty, Siirt University, 56100 Siirt, Turkey
}

\section{A R T I C L E I N F O}

Article history:

Received 30 September 2016

Accepted 08 December 2016

Available online, ISSN: $2148-127 \mathrm{X}$

Keywords:

Deficit irrigation

Dry matter

Silage maize

Water use efficiency

Quality

Corresponding Author:

E-mail: alibeyhanucak@gmail.com

\section{A B S T R A C T}

The present study was carried out to investigate the effects of different water deficit levels applied through growing season on silage yield, quality and water use efficiency (WUE) of main crop silage maize under semi-arid climate conditions during the years 2014 and 2015. Irrigation treatments were set as 100\% $\left(\mathrm{I}_{100}\right), 70 \%\left(\mathrm{I}_{70}\right)$ and 35\% $\left(\mathrm{I}_{35}\right)$ supply of depleted water within $0-90 \mathrm{~cm}$ effective root zone in 7-day intervals. Applied irrigation water quantities in $\mathrm{I}_{100}$ (control) treatment of the first and second year (in 8 irrigations) were respectively observed as 693 and $666 \mathrm{~mm}$. Plant water consumptions in control treatment were respectively measured as 770 and $738 \mathrm{~mm}$. Silage yield was $10650 \mathrm{~kg} \mathrm{da}^{-1}$ in the first year and $10600 \mathrm{~kg} \mathrm{da}^{-1}$ in the second year. The silage yield obtained from $\mathrm{I}_{70}$ treatment with $30 \%$ water deficit was statistically placed in group (B) following $\mathrm{I}_{100}$ (control) treatment. The water deficits over $30 \%$ resulted in significant decreases in silage yield and quality. The correlation coefficient between ETa and dry matter was respectively identified as (r: 0.78), (r: 0.87) in 2014 and 2015 and the correlation coefficient between plant water consumption (ETa) and protein content was respectively identified as (r:0.81), (r:0.80) and the correlations between ETa and quality parameters were found to be positive and highly significant. There were significant linear correlations between ETa and kernel yield (Y). Yield response factor (ky) of experimental years were respectively calculated as 0.74 and 1.06 . Irrigation water use efficiency (IWUE) values varied between $3.80-5.10 \mathrm{~kg} \mathrm{da}^{-1} \mathrm{~mm}$ and water use efficiency (WUE) values varied between 3.62 and $4.42 \mathrm{~kg} \mathrm{da}^{-1} \mathrm{~mm}$.

Türk Tarım - Gıda Bilim ve Teknoloji Dergisi, 4(12): 1228-1239, 2016

\section{Kısıntılı Sulama Uygulamalarının Silajlık Mısırın Verim, Kalite ve Su Kullanım Randımanı Üzerine Etkileri}

\section{A K A L E B İ L G İ S İ}

Geliş 30 Eylül 2016

Kabul 08 Aralık 2016

Çevrimiçi baskı, ISSN: 2148-127X

\section{Anahtar Kelimeler:}

Kisintilı sulama

Kuru madde

Silajlık misır

Su kullanım etkinliği

Kalite

"Sorumlu Yazar:

\section{Ö Z E T}

$\mathrm{Bu}$ araştırma yarı kurak iklim koşullarında, yetişme sezonu süresince farklı düzeylerde oluşturulan su kısıntısının ana ürün silajlık mısırın silaj verimine, kalitesine ve su kullanım randımanı üzerine (WUE) etkilerini belirlemek amacıyla, 2014 ve 2015 yıllarında yürütülmüştür. Araştırmada sulama konuları, her 7 günde bir 0-90 cm'lik etkili kök derinliğinde tüketilen suyun \%100 (I100), \%70 (I70), \%35 (I35)'inin yeniden uygulanması şeklinde oluşturulmuştur. Çalışmada, bitki kök bölgesindeki eksik nemin tamamının karşılandığı I100 (kontrol) konusuna denemenin ilk ve ikinci yılında 8'er kez, sırasıyla toplam 693 ve $666 \mathrm{~mm}$ sulama suyu uygulanmıştır. Kontrol konusunun bitki su tüketimi değeri birinci yıl $770 \mathrm{~mm}$, ikinci yıl ise $738 \mathrm{~mm}$ olarak bulunmuştur. Anılan sulama konusunda silaj verimi denemenin birinci yllında $10650 \mathrm{~kg} / \mathrm{da}$, ikinci yılında $10600 \mathrm{~kg} / \mathrm{da}$ arasında değişmiştir. \% 30 oranında su kısıntıs1 uygulanan I70 konusundan alınan silaj verimi istatistiksel olarak I100 (kontrol) konusuna yakın grupta (B) yer almıştır. \%30 oranından daha fazla yapılan su kısıntıları silaj verimi ve kalitesinde önemli oranda azalışlara sebep olmuştur. Ayrıca ET ile kuru madde arasında korelasyon katsayısı (r:0.78**-r:0.87**) ve ET ile silaj verimi, protein miktarı arasında korelasyon katsayısı sırasıyla (r:0.81**) ve (r:0.80**), olarak belirlenmiş ve ETa ile kuru madde ve protein miktarı arasında istatistiki olarak önemli pozitif yönde yüksek bir ilişki bulunmuştur. Sulama suyu (I) ve su tüketim (ETa) değerleri ile tane verimi (Y) arasında \%1 önem düzeyinde doğrusal ilişkiler belirlenmiştir. Deneme yıllarında sırasıyla verim tepki etmeni (ky) 0.74 ve 1.06 olarak bulunmuştur. Konulara göre sulama suyu kullanım randımanı (IWUE), 3.80-5.10 $\mathrm{kg} \mathrm{da}^{-1} \mathrm{~mm}$; su kullanım randımanı (WUE) ise 3.62 ile $4.42 \mathrm{~kg}$ $\mathrm{da}^{-1} \mathrm{~mm}$ arasında değişmiştir. 


\section{Introduction}

About $22 \%$ of daily calorie consumption of the world is supplied from maize. Since maize is available for machine cultivation and has quite high yield levels, it plays a significant role in both human and animal nutrition. Annual silage corn production of Turkey is around 14 million tons (TUIK, 2014). However, the country need is about 18 million tons. The remaining 4 million tons are supplied through imported raw materials. The best quality and optimum silage is obtained from maize both in Turkey and throughout the world. About 95\% silage production of Turkey is obtained from maize. The present research site, Southeastern Anatolia region of Turkey meets about $27.6 \%$ of country maize (Zea mays L.). The region has also quite intense dairy and goat production activities. Therefore, silage maize production is of great significance for the region. Although quality is a quite significant factor in forage crops, it is most of the time disregarded. Biomass quality or nutritional value is generally assessed with chemical composition or digestibility parameters (Budak and Budak, 2014). Karakozak and Ayasan (2010) indicated maize as the most commonly ensilaged crop in Turkey because of various positive attributes such as high dry matter content, low buffering capacity and available carbohydrate levels for lactic acid fermentation. Carpici et al. (2010) indicated plant density and nitrogen treatments as the significant factors effecting silage maize yield and silage quality.

Insufficient water resources have become a serious concern in some parts of the world (Kang and Zhang 2004). Before deficit irrigation can be accepted as a management strategy, potential effects on yield, quality and net income should be determined based on wateryield relationships and economic evaluation assessments (Kuscu et al., 2014). There are several inputs in maize (Zea mays L.) culture and irrigations constitute a significant portion of input costs in regions especially with deficit and expensive water resources. Since climate and soil characteristics vary from one region to another, the most proper irrigation programs should be developed for the region in concern. With a well-designed irrigation program, it is quite possible to provide efficient use of production inputs like water, energy and fertilizer. The present research site is located within semi-arid climate zone and has quite limited water resources. Therefore in maize culture of the region, required irrigation water should be supplied at proper periods in proper amounts with a proper method as to provide water saving and high water use efficiencies. Right at this point, water production functions come into scene especially in semiarid and arid climates with deficit water resources.

Water production functions aim to irrigate more fields with the each unit of saved water. "Water-production" functions are also used to estimate economic outcomes of the decisions made by planners related to optimal water distribution plans. On the other hand, water production functions provide significant clues in assessment of irrigation system capacities, irrigation programs and water use efficiencies (Sammis, 1981; Gencoglan and Yazar, 1999). Such functions are also employed in assessment of plant water requirements, plant growth models, water use efficiencies and irrigation schedules, in water distribution operations and design, operation and economic analysis of irrigation systems (Howell and Musick, 1985; Gencoglan, 1999). The basic target in deficit irrigation is to increase WUE values and to get the maximum yield from each drip of water (Kirda, 2002)

In deficit irrigation, water is saved by applying less water than plant requirement and the saved amount is used to irrigate more fields, in other words to open new fields for irrigation. Plant water requirement is reduced to a point over the production function in which reduction in income is equal to production costs. Since less water is applied to plants than their actual water requirement, a certain amount of yield is evident or a certain amount of yield loss is allowed in deficit irrigation.

Recent increases in maize cultivated lands and high water requirement of maize may exert an increasing water deficit pressure over the producers of Southeastern Anatolia region in near future. On the other hand, current climate change and resultant global warming also result in water deficits. Such cases require optimum use of water resources for the sustainability of agricultural activities. However, number of studies about the effects of deficit irrigation treatments on maize silage yield and quality and water use efficiency under semi-arid climate conditions is not sufficient. Therefore, the present study was carried out to investigate the effects of different deficit irrigation treatments on yield and quality of maize silage and water use efficiencies.

\section{Material and Methods}

The present research was carried out throughout the growing season of maize in 2014 and 2015 over the experimental fields of Siirt University Agricultural Faculty. Experimental fields are located at $37^{\circ} 58^{\prime} \mathrm{N}$ latitude and $41^{\circ} 50^{\prime} \mathrm{E}$ longitude and have an altitude of $894 \mathrm{~m}$. P30B74 maize cultivar was used as the plant material of the study.

Long-term and experimental year climate data of the experimental site (throughout the maize growing season) are provided in Table 1. The region has terrestrial climate characterized by precipitated and cold winter months and dry and hot summer months. It was observed that mean temperature in summer was over $26^{\circ} \mathrm{C}$ and mean temperature in winter was over $2.7^{\circ} \mathrm{C}$, maximum longterm annual mean relative humidity $(70.2 \%)$ was seen in January and minimum (26.9\%) in August. Annual mean relative humidity of the region is $50.41 \%$. Long-term mean precipitation is $669.2 \mathrm{~mm}$ and monthly precipitations vary between 103.6 - $1.3 \mathrm{~mm}$ (DMI, 2016).

Before sowing, disturbed and undisturbed soil sampling was performed from three different soil layers as of $0-30,30-60$ and $60-90 \mathrm{~cm}$ to find out physical and chemical properties of experimental soils. Three undisturbed and one disturbed soil sample were taken from each layer. Undisturbed soil samples were taken into $100 \mathrm{~cm}^{3}$ steel tubes. Macro, micro and total porosity of these samples were determined in accordance with Danielson and Sutherlend (1986); water holding capacity at field capacity $(33 \mathrm{kPa})$ was determined in accordance with Klute (1986); soil bulk density was determined in 
accordance with Blake and Hartge (1986). Disturbed soil samples were subjected to organic matter, texture and permanent wilting point analyses. Organic matter content was determined with Walkey-Black dichromate oxidation method (Nelson and Sommers, 1996), water holding capacity at permanent wilting point $(1500 \mathrm{kPa})$ was determined in accordance with Klute (1986) and texture was analyzed through hydrometer method in accordance with Bouyoucos (1962).

The resultant data on soil characteristics are provided in Table 2. Experimental soils were classified under brown forest soils (Dengiz et al., 2013). Soil texture was clay with low electrical conductivity, medium lime, low phosphorus, high potassium and medium organic matter contents. Field capacity (FC) was found to be $443 \mathrm{~mm}$ in depth for $0-90 \mathrm{~cm}$ soil profile, permanent wilting point (PWP) was found to be $322 \mathrm{~mm}$, soil bulk density was measured as $1.40 \mathrm{gr} \mathrm{cm}^{-3}$ and available water holding capacity was found to be $121 \mathrm{~mm}$. The methods specified in Tuzuner (1990) were used to determine irrigation water quality parameters ( $\mathrm{EC}, \mathrm{pH}$, anion and cation). Irrigation water quality class was identified as $\mathrm{C}_{2} \mathrm{~S}_{1}$ (with and EC of $0.34 \mathrm{dS} \mathrm{m}^{-1}$ and a $\mathrm{pH}$ of 7.21). Irrigation water was not considered to pose any problems to growth of maize plants.

Experiments were conducted in randomized blocks split plots experimental design with 3 replications. Three different irrigation treatments were set as $I_{100}, I_{70}$ and $I_{35}$. Irrigation interval was selected as one week. Irrigation treatments were set as full irrigation in which $100 \%$ of depleted water in $90 \mathrm{~cm}$ soil profile in a week was supplied ( $\mathrm{I}_{100}$, control treatment), 30\% deficit irrigation in which $70 \%$ of full irrigation was applied $\left(\mathrm{I}_{70}\right)$ and $65 \%$ deficit irrigation in which $35 \%$ of full irrigation was applied $\left(\mathrm{I}_{35}\right)$. In this way, 3 irrigation treatments were formed as of 1 full and 2 deficit irrigations.

For water conveyance and distribution into plots, PE pipes with $63 \mathrm{~mm}$ outer diameter and 10 atm operational pressure were used. In drip irrigation, a lateral line was installed for each plant row $(70 \mathrm{~cm})$. Water distribution within the plots was carried out through soft PE pipe lines with $20 \mathrm{~mm}$ outer diameter and 4 atm operational pressure. Experimental soils have heavy texture with an infiltration rate of $7 \mathrm{~mm} \mathrm{~h}^{-1}$. Dripper spacing was $0.30 \mathrm{~m}$, dripper discharge rate was $4 \mathrm{~L} \mathrm{~h}^{-1}$. In-line pressure regulated drippers work at 1 atm operational pressure. Since irrigation water was applied at plant requirement, deep percolation or runoff was not encountered. Seed bed was prepared as to have planting over the ridges. Each plot had 4 rows $70 \mathrm{~cm}$ apart and on-row plant spacing was $18 \mathrm{~cm}$. Plots were $6 \mathrm{~m}$ long and $2.8 \mathrm{~m}$ wide $\left(16.8 \mathrm{~m}^{2}\right)$. Sowing was performed with a 4-row pneumatic single seed planter and seeds were dropped at $4-5 \mathrm{~cm}$ depth. Buffer zones of $2 \mathrm{~m}$ were placed to prevent interactions between the plots and replications.

All of phosphorus fertilizer $\left(9 \mathrm{~kg} \mathrm{da}^{-1}\right.$ as pure $\left.\mathrm{P}_{2} \mathrm{O}_{5}\right)$ and one-third of nitrogenous fertilizer $\left(28 \mathrm{~kg} \mathrm{da}^{-1} \mathrm{~N}\right)$ were supplied at the time of sowing and the remaining twothird of nitrogen was supplied in two doses at a plant height around 40-50 cm (Hammad et al. 2012).

Following the emergence, thinning was performed among close plants at a plant height of around $15-20 \mathrm{~cm}$, hoeing and earthing up were performed when the plants had 8-9 leaves. Herbicides were not used since an intense weed invasion was not observed; only mechanical weed control was preferred. Since there wasn't any high epidemy to common maize stalk worm and cob worm, pesticides were not also used. Before each irrigation, moisture content at efficient root depth $(90 \mathrm{~cm})$ was determined with gravimetric method. The amount of irrigation water to be applied in each irrigation was determined based on full irrigation treatment $\left(\mathrm{I}_{100}\right)$ as to bring the deficit moisture in $90 \mathrm{~cm}$ soil profile into the field capacity. Therefore, before each irrigation, soil moisture content in 0-30, 30-60 and 60-90 cm layers was determined in dry-weight base (\%). Then the dry-weightbased moisture contents for each layer were converted into depths by using the Equation 1; (Eq. (1)).

Table 1 Climate data of the experimental area for the growing seasons of 2014-2015 and from 1962 to 2014

\begin{tabular}{|c|c|c|c|c|c|c|c|c|c|c|}
\hline Years & Months & $\begin{array}{c}\mathrm{MMXT} \\
\left({ }^{\circ} \mathrm{C}\right)\end{array}$ & $\begin{array}{l}\mathrm{MT} \\
\left({ }^{\circ} \mathrm{C}\right) \\
\end{array}$ & $\begin{array}{c}\mathrm{MMNT} \\
\left({ }^{\circ} \mathrm{C}\right)\end{array}$ & $\begin{array}{l}\mathrm{MH} \\
(\%)\end{array}$ & $\begin{array}{c}\text { MWS } \\
(\mathrm{m} \mathrm{s}-1)\end{array}$ & $\begin{array}{l}\text { MDS } \\
\text { (h) }\end{array}$ & $\begin{array}{c}\mathrm{TR} \\
(\mathrm{mm})\end{array}$ & $\begin{array}{l}\text { MST } \\
\left({ }^{\circ} \mathrm{C}\right) \\
\end{array}$ & $\begin{array}{c}\mathrm{TE} \\
(\mathrm{mm})\end{array}$ \\
\hline & May & 25.2 & 19.4 & 9.0 & 49.3 & 1.0 & 9.1 & 36.9 & 19.5 & 67.4 \\
\hline Average & June & 27.2 & 26.0 & 17.8 & 34.9 & 1.1 & 11.6 & 11.5 & 26.0 & 162.2 \\
\hline 1962 - & July & 35.1 & 30.5 & 23.4 & 30.3 & 1.1 & 12.3 & 0.6 & 30.8 & 217.2 \\
\hline \multirow[t]{4}{*}{2014} & August & 34.5 & 30.3 & 27.0 & 29.5 & 1.0 & 11.4 & 2.7 & 31.8 & 231.0 \\
\hline & September & 30.0 & 25.1 & 14.7 & 37.4 & 1.0 & 10.1 & 7.0 & 29.9 & 48.3 \\
\hline & May & 27.07 & 20.88 & 14.79 & 41.40 & 1.1 & 8.9 & 18.6 & 20.1 & 41.6 \\
\hline & June & 32.98 & 26.95 & 19.57 & 24.82 & 1.0 & 11.8 & 15.1 & 25.6 & 161.0 \\
\hline \multirow[t]{5}{*}{2014} & July & 38.09 & 31.48 & 24.15 & 19.05 & 1.2 & 12.1 & 0.10 & 30.4 & 208.6 \\
\hline & August & 38.35 & 31.38 & 24.34 & 17.95 & 1.1 & 11.6 & 5.20 & 31.2 & 221.7 \\
\hline & September & 31.75 & 24.63 & 19.31 & 34.90 & 1.0 & 10.0 & 32.1 & 30.3 & 50.6 \\
\hline & May & 26.62 & 21.29 & 14.52 & 38.87 & 1.0 & 8.7 & 29.6 & 20.6 & 51.9 \\
\hline & June & 33.09 & 28.16 & 20.0 & 25.50 & 1.1 & 12.0 & 3.6 & 27.4 & 170.7 \\
\hline \multirow[t]{3}{*}{2015} & July & 39.13 & 31.19 & 24.35 & 20.69 & 1.0 & 12.4 & 0.1 & 31.3 & 228.3 \\
\hline & August & 38.92 & 31.45 & 24.23 & 23.95 & 1.0 & 11.8 & 6.0 & 32.6 & 243.1 \\
\hline & September & 35.23 & 27.43 & 21.5 & 31.90 & 1.1 & 10.0 & 0.2 & 30.5 & 61.4 \\
\hline
\end{tabular}

MWS: Mean wind speed (m s-1), MDS: Mean daily sunshine (h), TR: Total rain (mm), MST: Mean 50cm soil temperature $\left({ }^{\circ} \mathrm{C}\right)$, TE: Total evaporation $(\mathrm{mm})$ 
Table 2 Soil physical and chemical properties of the experimental fields

\begin{tabular}{l|rrr}
\hline \multicolumn{1}{c|}{ Properties } & \multicolumn{3}{c}{ Soil layer $(\mathrm{cm})$} \\
\cline { 2 - 4 } & $0-30$ & $30-60$ & $60-90$ \\
\hline Texture & Clay & Clay & Clay \\
Clay (\%) & 57.12 & 55.12 & 53.12 \\
Silt (\%) & 22.0 & 16.0 & 14.0 \\
Sand (\%) & 20.88 & 24.88 \\
Field capacity (Pw) & 33.52 & 35.38 \\
Wilting point (Pw) & 24.44 & 36.04 & 25.57 \\
Bulk density $\left(\mathrm{g} \mathrm{cm}^{-3}\right)$ & 1.42 & 26.08 & 1.41 \\
pH $(1: 2.5$ s/w) & 7.50 & 1.39 & 7.91 \\
Electrical conductivity $\left(\mathrm{dS} \mathrm{m}^{-1}\right)$ & 1.55 & 7.66 & 1.75 \\
Organic matter $(\%)$ & 3.09 & 1.77 & 1.80 \\
$\mathrm{CaCO}_{3}(\%)$ & 6.4 & 2.06 & 1.9 \\
\hline
\end{tabular}

$$
\mathrm{d}=(\mathrm{FC}-\mathrm{Pw}) \mathrm{AsxD} / 100
$$

Where; d: soil moisture content in depth $(\mathrm{mm}), \mathrm{FC}$ : Field Capacity (\%), Pw: dry weight-based moisture content of each layer (\%), As: soil bulk density $\left(\mathrm{g} \mathrm{cm}^{-3}\right)$ and D: depth of layer ( $\mathrm{mm})$. Then, the moisture depths calculated for each layer are summed up to get total moisture content in depth $\left(\mathrm{d}_{\mathrm{T}}\right)$ for efficient root depth $(\mathrm{Eq}$ (2)):

$$
\mathrm{d}_{\mathrm{T}}=\mathrm{d}_{(0-30)}+\mathrm{d}_{(30-60)}+\mathrm{d}_{(60-90)}
$$

Volume of water to be applied to each plot was calculated with Equation 3 by multiplying plot size, deficit ratio $(1.0,0.70,0.35)$ and cover ratio (Eq. (3)):

$$
\mathrm{V}=\mathrm{d}_{\mathrm{T}} \mathrm{xAxU_{ \textrm {o } } \mathrm { xP }}
$$

Where; V: Volume of water to be applied (L), A: plot size $\left(\mathrm{m}^{2}\right)$, Uo: deficit ratio $(\%)$ and $\mathrm{P}$ : cover ratio $(\%)$.

Cover ratio was calculated through dividing plant canopy width by plant row spacing. Cover ratio (CR) was taken as 0.30 until $30 \%$ cover, as the calculated value until $80 \%$ cover and fixed at $80 \%$ at further values. The principles in Howell (2006) were considered to determine the amount of water to be used in each plot. Water applications were performed in a controlled manner through water meters and continuous dripper discharge checks. Monthly and seasonal evapotranspiration values were calculated with water balance method by using weekly soil moisture measurements $(90 \mathrm{~cm})$ throughout the growing season, at the beginning and end of harvest (Zeleke and Wade, 2012).

Water use efficiency (WUE) was calculated through dividing dry biomass yield $\left(\mathrm{kg} \mathrm{ha}{ }^{-1}\right)$ by seasonal evapotranspiration $(\mathrm{mm})$ value and irrigation water use efficiency (IWUE) was calculated through dividing dry biomass yield $\left(\mathrm{kg} \mathrm{ha}{ }^{-1}\right)$ by the amount of applied irrigation water $(\mathrm{mm})$ (Scott, 2000). The following water balance equation was used to calculate plant water consumptions (Eq. (4)) (Zeleke and Wade, 2012).

$$
\mathrm{ETa}=\mathrm{P}+\mathrm{I}-\mathrm{R}_{\mathrm{f}}-\mathrm{D}_{\mathrm{p}} \pm \Delta \mathrm{S}
$$

Where; ETa: Evapotranspiration (mm), P: precipitation $(\mathrm{mm})$, I: amount of irrigation water $(\mathrm{mm})$; $\mathrm{R}_{\mathrm{f}}$ : runoff $(\mathrm{mm}) ; \mathrm{D}_{\mathrm{p}}$ : deep percolation $(\mathrm{mm})$ and $\pm \Delta \mathrm{S}$ $(\mathrm{mm})$ : change in soil water storage in root zone.

Since the discharge of selected drippers was lower than soil infiltration rate, runoff was not encountered. Since a certain amount of water was applied to bring the current moisture levels into field capacity, deep percolation was not also observed.

The equations provided in Scott (2000) were used to calculate irrigation water use efficiency (IWUE) and water use efficiency (WUE) values (Eq. $(5,6))$.

IWUE = Y/I

$\mathrm{WUE}=\mathrm{Y} / \mathrm{Eta}$

ETa: Evapotranspiration ( $\mathrm{mm})$

I: amount of irrigation water ( $\mathrm{mm})$

Where;

IWUE: Total irrigation water use efficiency $\left(\mathrm{kg} \mathrm{da}^{-1} \mathrm{~mm}\right)$

WUE: Total water use efficiency $\left(\mathrm{kg} \mathrm{da}^{-1} \mathrm{~mm}\right)$

Y: Dry matter yields of irrigation treatments

The relationship between relative evapotranspiration reduction (1-Eta ${ }^{-1}$ Etm) and relative yield reduction (1$\mathrm{Ya}^{-1} \mathrm{Ym}$ ) was determined using the method given by Doorenbos and Kassam (1979). The equations are as follows (Eq. (7)).

$$
\left(1-\frac{Y a}{Y m}=k y\left(1-\frac{E T_{a}}{E T_{m}}\right)\right.
$$

Where; Ya is actual harvested yield $\mathrm{kg} \mathrm{da}^{-1}, \mathrm{Ym}$ is maximum harvested yield, ky is yield response factor, ETa is actual evapotranspiration, ETm is maximum evapotranspiration.

Following the entire measurements over the experimental plots, harvest was performed at milk-dough stage (Alkhamisi et al., 2011). Side rows were omitted and $0.5 \mathrm{~m}$ from top and bottom of the rows were not also considered, thus harvest was made from $5 \mathrm{~m}$ sections of inner rows (harvested plot size: $7 \mathrm{~m}^{2}$ ). Fresh biomass yield was determined at harvest. Then, randomly selected 5 plants from each plot were dried at $65^{\circ} \mathrm{C}$ until a constant weight to determine dry matter weights.

Dried samples were grinded in a mill with $1 \mathrm{~mm}$ screen. Nitrogen $(\mathrm{N})$ contents of samples were determined with Kjeldahl method and crude protein ratios were calculated as ( $\mathrm{N}$ x 6.25) (Kacar and Inal, 2008). Chemical 
analyses were performed to assess feed quality and silage quality of silage maize. Dry matter analyses were performed in accordance with Weende analysis method (Nehring 1960). Acid Detergent Fiber (ADF) and Neutral Detergent Fiber (NDF) analyses were carried out in accordance with the principles specified in Van Soest et al. (1991) with an ANKOM Fiber Analyzer device. Digestible dry matter (DDM) ratio was calculated by using ADF values with the following equation (Eq. (8)) (Ayasan and Karakozak, 2012).

$$
\% \mathrm{DDM}=88.9-(0.779 * \% \mathrm{ADF})
$$

Where; DDM: Digestible dry matter (\%) and ADF: Acid Detergent Fiber (\%).

In this study, leaf areas were measured with the following equation (Eq. (9)) proposed by Stewart and Dwyer (1999). Leaf area measurements were made once in flowering period. For measurements, 3 plants from the $2^{\text {nd }}$ and $3^{\text {th }}$ rows of all plots were cut from the soil surface and sampled. Total leaf area of a plant was proportioned to area of a plant in order to calculate the Leaf Area Index (Eq. (10)).

$$
\mathrm{LA}=\mathrm{Wm} \times \mathrm{L} \times 0.743
$$

Where; Wm: Maximum leaf width $(\mathrm{cm})$ and L: Leaf size $(\mathrm{cm})$.

Leaf Area Index (LAI) was calculated using the equation below.

$$
\mathrm{LAI}=\mathrm{YA} / \mathrm{PA}
$$

Where; LAI: Leaf Area Index, YA: Leaf area $\left(\mathrm{cm}^{2}\right)$, PA: Plant area $\left(\mathrm{cm}^{2}\right)$

All the data acquired through these methods have been subjected to an Analysis of Variance (ANOVA) in randomized blocks - split plots design. Based on the results obtained from the analysis of variance, the significant treatments were compared with LSD (Least Significant Difference) test.

\section{Results and Discussion}

\section{Water-Yield Relationship}

Right after sowing on 19 May 2014 in the first year and on 20 May 2015 in the second year, irrigation water was supplied through drip irrigation to bring the soil moisture in $0-90 \mathrm{~cm}$ soil profile to field capacity $(59 \mathrm{~mm}$ in the first year and $52 \mathrm{~mm}$ in the second year), thus to provide a homogenous emergence. Higher irrigation water supply of the first year was because $29.6 \mathrm{~mm}$ precipitation was observed in May 2015 in which sowing was performed.

Irrigation treatments were initiated together with earthing up (when the plants had 6-8 leaves) on 04.05.2014 in the first year and on 05.07.2015 in the second year (44 and 45 days after sowing) when $50 \%$ of available moisture was depleted (Howell 2001) and treatments were terminated at the beginning of dough stage on 22.08.2014 in the first year and on 23.08.2015 in the second year (93 and 94 days after sowing). A total of
8 irrigations were performed through drip irrigation in both years. Harvest times varied between 105 days (03.09.2015) in deficit irrigations and 115 days (13.09.2015) in full irrigation. Harvest was performed 10 days earlier in deficit irrigations than in full irrigation.

Amount of irrigation water applied to irrigation treatments and plant water consumptions under semi-arid climate conditions of the present study and relevant statistical analysis results (LSD groups) are provided in Table 3.

Weekly amount of irrigation water applied in irrigation treatments varied between 54-68 mm. While daily water requirement varied between 3.5-4.5 $\mathrm{mm} \mathrm{day}^{-1}$ in early vegetative period, the value reached to maximum level $\left(9 \mathrm{~mm} \mathrm{day}^{-1}\right)$ in pre-blooming, blooming and cob kernel-set periods. In full irrigation treatment $\left(\mathrm{I}_{100}\right)$, the amount of irrigation water applied in the first and second year was respectively measured as 693 and $666 \mathrm{~mm}$. In relevant irrigation treatment, amount of applied irrigation water was more than the other treatment. Such a higher value was because of greater plant cover ratio and thus higher transpiration in $\mathrm{I}_{100}$ treatment. In previous studies carried out about water-yield relationships in maize plants, the amount of irrigation water applied in full irrigation treatments in which soil moisture depletion was fully met varied between 263-1206 $\mathrm{mm}$. The values were reported as between $752-823 \mathrm{~mm}$ by Gencoglan and Yazar (1999); between 463-477.7 mm by Bouazzama et al. (2012); between 814-1206 mm by Simsek and Gercek (2005); between 562-619 $\mathrm{mm}$ by Ucak et al. (2013); between 459-514 $\mathrm{mm}$ by Yolcu and Cetin (2015); as $813.9 \mathrm{~mm}$ by Isik et al. (2012) and between 263-322 mm by Ariturk and Erdem (2011). Current values were lower than the values reported by Gencoglan and Yazar (1999), Isik et al. (2012) and Simsek and Gercek (2005), higher than the values reported by Bouazzama et al. (2012), Yolcu and Cetin (2015) and Ariturk and Erdem (2011) and relatively coincided with the values reported by Ucak et al. (2013). Such different results were mainly because of different soil, climate and environmental conditions, irrigation programs and cultural practices (Igbadun et al. 2008).

Seasonal plant water consumption (ETa) values of full irrigation $\left(\mathrm{I}_{100}\right)$ and excessive water deficit treatment $\left(\mathrm{I}_{35}\right)$ were respectively observed as 770 and $411 \mathrm{~mm}$ in the first year and 738 and $390 \mathrm{~mm}$ in the second year. The plant water consumptions in the other irrigation treatment $\left(\mathrm{I}_{70}\right)$ were between the values of the other two treatments. In the first year, plant water consumption of $\mathrm{I}_{100}$ treatment was $359 \mathrm{~mm}$ higher than $I_{35}$ and $161 \mathrm{~mm}$ higher than $I_{70}$ treatment. In the second year, plant water consumption of $\mathrm{I}_{100}$ treatment was $348 \mathrm{~mm}$ higher than $\mathrm{I}_{35}$ and $155 \mathrm{~mm}$ higher than $I_{70}$ treatment. The reasons for such higher values were higher leaf area index values (LAI) of $\mathrm{I}_{100}$ treatment (4.65) than $I_{35}$ treatment (3.22) (Table 3). Soil moisture content and seasonal plant water consumption values were lower in deficit irrigation treatments. Norwood and Dumler (2002), Li et al. (2004) and Kuscu (2010) carried out deficit irrigation researches on maize plants and reported similar results with the present study. Seasonal water consumption of maize plants was reported as $562 \mathrm{~mm}$ by Kaman (2007) for P31G98 cultivar and 405 
$\mathrm{mm}$ for Tietar cultivar in the first year; as $580 \mathrm{~mm}$ for P31G98 and $421 \mathrm{~mm}$ for Rx. 9292 cultivar in the second year. Gencoglan and Yazar (1999) reported values ranging from 1.026 (fully irrigated) to $410 \mathrm{~mm}$ (nonirrigated) in Cukurova region, Katerji et al. (1996) reported the values as between 494-644 mm, Pandey et al. (2000) between 641-668 mm, Kiziloglu et al. (2009) between 512.6-688.4 mm, Payero et al. (2006) between
625-366 mm. Greenwood et al. (2008) indicated that amount of rainfall and irrigation for silage maize irrigated by center pivot method was $782 \mathrm{~mm}$ in northern Victoria. Present findings were lower than the values reported by Gencoglan and Yazar (1999), higher than the values reported by Katerji et al. (1996), Pandey et al. (2000), Kiziloglu et al. (2009) and Payero et al. (2006) and were quite similar to ones reported by Greenwood et al. (2008).

Table 3 Means and LSD groups for applied irrigation water, ETa and other parameters

\begin{tabular}{|c|c|c|c|c|c|c|c|c|c|c|c|c|}
\hline IR & MI & MET & $\mathrm{DM}^{* *}$ & WUE & IWUE & $\mathrm{PH}^{* *}$ & LAI** & DDM & FB** & PC** & $\mathrm{ADF}$ & NDF \\
\hline \multicolumn{13}{|c|}{2014 (Year) } \\
\hline $\mathrm{I}_{100}$ & 693 & 770 & $34056^{\mathrm{a}}$ & 4.42 & 4.91 & $354^{\mathrm{a}}$ & $4.66^{\mathrm{a}}$ & $70.6^{\mathrm{a}}$ & $106499^{\mathrm{a}}$ & $8.62^{\mathrm{a} * * *}$ & & \\
\hline $\mathrm{I}_{70}$ & 527 & 609 & $26782^{\mathrm{b}}$ & 4.39 & 5.10 & $330^{\mathrm{b}}$ & $3.91^{\mathrm{b}}$ & $70.2^{\mathrm{b}}$ & $84417^{b}$ & $8.23^{\mathrm{b}}$ & & \\
\hline & 392 & 411 & $14971^{\mathrm{c}}$ & 3.65 & 3.82 & $283^{c}$ & $3.27^{\mathrm{c}}$ & $69.5^{\mathrm{c}}$ & $63394^{c}$ & $7.17^{\mathrm{c}}$ & & \\
\hline LSD (0.05) & & & 214.1 & & & 4.8 & 0.08 & 0.073 & 136.1 & 0.039 & ns & ns \\
\hline \multicolumn{13}{|c|}{2015 (Year) } \\
\hline $\mathrm{I}_{100}$ & 666 & 738 & $32360^{\mathrm{a}}$ & 4.38 & 4.86 & $350^{\mathrm{a}}$ & $4.63^{\mathrm{a}}$ & $70.0^{\mathrm{a}}$ & $106005^{\mathrm{a}}$ & $7.53^{\mathrm{a}} * * *$ & & \\
\hline $\mathrm{I}_{70}$ & 509 & 583 & $25500^{\mathrm{b}}$ & 4.37 & 5.00 & $331^{\mathrm{b}}$ & $4.04^{\mathrm{b}}$ & $69.3^{\mathrm{a}}$ & $84240^{\mathrm{b}}$ & $7.26^{\mathrm{b}}$ & & \\
\hline & 371 & 390 & $14130^{\mathrm{c}}$ & 3.62 & 3.80 & $274^{\mathrm{c}}$ & $3.16^{\mathrm{c}}$ & $67.2^{\mathrm{b}}$ & $63402^{c}$ & $7.19^{\mathrm{b}}$ & & \\
\hline $\operatorname{LSD}(0.05)$ & & & 26.2 & & & 10.9 & 0.45 & 0.94 & 34.0 & 0.10 & ns & ns \\
\hline
\end{tabular}

IR: Irrigation treatments, MI: Mean İrrigatio (mm), MET: Mean Eta (mm), DM: Dry matter (kg/ha), WUE: Total water use efficiency (kg/da/mm), IWUE: Total irrigation water use efficiency $(\mathrm{kg} / \mathrm{da} / \mathrm{mm})$, PH: Plant height $(\mathrm{cm})$, LAI: Leaf area index, DDM: Digestible dry matter $(\%)$, FB: Fresh biomass (kg/ha), PC: Protein content (\%),ADF: Acid Detergent Fiber (\%), NDF: Neutral Detergent Fiber (\%), *significant at P $\leq 0.05, * *$ significant at $\mathrm{P} \leq 0.01$, ns: not significant, $* * *$ The plants were given equal watering applications until reaching $40-50 \mathrm{~cm}$. Hence, the reason why the water consumption values of the irrigation subjects I70 and I35 are high is due to this.

Seasonal water consumption of the same cultivar may differ in different climates and regions. It may even be different within the same region. Such differences may be resulted from differences in climate, plant, soil characteristics, irrigation programs and methods and other cultural practices. Abiotic stress factors (temperature, relative humidity, wind) in blooming period may significantly decrease kernel formation in cobs and increase evapotranspiration rates.

\section{Dry Matter (DM)}

The results on dry matter yields of irrigation treatments are provided in Table 3. Dry matter yields were low in early and mid-vegetative period, values increased in blooming period and reached to optimum levels in dough stage. Photosynthesis reaction and organic matter production capacity is generally not at maximum level in germination and early-vegetative stages of the plants since number of leaves and sizes are not sufficient in these stages. Since carbon dioxide fixation and thus organic matter production are quite low, dry matter production is also less in these stages. The organic matter synthesized in leaves through photosynthesis to form the kernels is transferred to generative organs, thus quite high amount of organic matter is accumulated in blooming period with full irrigation. Therefore, higher dry matter contents are expected in blooming period. It was also stated in previous studies that $68-72 \%$ of carbohydrates accumulated in vegetative parts was transferred to form the kernels (Smith et al., 1999). Thus, high dry matter yields of full irrigation and low dry matter yields of deficit irrigations may be related to above mentioned processes (Yoshida, 1983).

Dry matter (DM) yield of the present study varied with irrigation treatments. In experimental years, the lowest dry matter yield was observed in $\mathrm{I}_{35}$ respectively with 14.970 and $14.130 \mathrm{t} \mathrm{ha}^{-1}$ and the highest value was observed in $\mathrm{I}_{100}$ respectively with 34.050 ve $32.360 \mathrm{t} \mathrm{ha}^{-1}$. The dry matter yields of the other irrigation treatments were observed as between these values (Table 3 ). The dry matter yield decreased by $22 \%$ with $30 \%$ deficit $(158$ $\mathrm{mm})$ and by $56.2 \%$ with $65 \%$ water deficit $(353.5 \mathrm{~mm})$. Such differences in dry matter yields of irrigation treatments were because of water deficits applied throughout the growing season. Increasing dry matter yields were observed with increasing water consumptions $\left(\mathrm{I}_{100}\right)$. This could be explained as such that dry matter (DM) accumulation increased by irrigation (Kiziloglu et al., 2009). Parallel to finding of Yolcu and Cetin (2015), decreasing dry matter contents were observed in this study with decreasing irrigation water quantities. Similarly, Li et al. (2004) reported $49 \%$ increase in maize yield with full irrigation $(295 \mathrm{~mm})$.

Maize dry matter yields were reported as between 23.2-30.0 $\mathrm{t} \mathrm{ha}^{-1}$ by Kiziloglu et al. (2009), between 3.9$16.4 \mathrm{t} \mathrm{ha}^{-1}$ by Bouazzama et al. (2012), as $22 \mathrm{t} \mathrm{ha}^{-1}$ by Greenwood et al. (2008) and as between 14.8-93.3 $\mathrm{t} \mathrm{ha}^{-1}$ by Yolcu and Cetin (2015). While the present findings were quite similar to ones reported by Yolcu and Cetin (2015), they were higher than the findings of the other researchers. Such differences between these studies were because of differences in irrigation methods, irrigation programs, local climate, soil and cultural techniques. Considering the photosynthesis metabolism, cells should have optimum moisture levels for plants to have desired photosynthesis rates and for photosystem reactions of chlorophylls to operate at optimum levels. In this case, with the aid of solar energy adsorbed by chlorophyll pigments, photolysis of water molecules takes place. Then with the photolysis of water, electrons and protons effective in organic matter formation through Calvin cycle of photosynthesis take place (Smith and Hamel, 1999). Ultimately, increase in dry matter yields in full irrigation $\left(\mathrm{I}_{100}\right)$ may be resulted from increased dry matter 
contents of the plants. As it can be seen from the correlation analyses (Table 4), correlation coefficient was determined as $(\mathrm{r}=0.80)$ and a significant positive correlation was observed between ET and dry matter at $1 \%$ significance level. Second-order significant linear relationships were observed between plant water consumption and dry matter yields of irrigation treatments $\left(\mathrm{I}_{35}, \mathrm{I}_{70}, \mathrm{I}_{100}\right)$ respectively as $\mathrm{Y}=2.072 \mathrm{ETa}+633\left(\mathrm{r}^{2}=0.95\right)$, $\mathrm{Y}=2.371 \quad$ ETa+663.1 $\quad\left(\mathrm{r}^{2}=0.96\right), \quad \mathrm{Y}=2.030 \quad \mathrm{ETa}+1635$ $\left(\mathrm{r}^{2}=0.98\right)$ in the first year and as $\mathrm{Y}=2.072 \mathrm{ETa}+633$ $\left(r^{2}=0.93\right), \quad Y=2.371 \quad$ ETa+663.1 $\quad\left(r^{2}=0.94\right), \quad Y=2.030$ $\mathrm{ETa}+1635\left(\mathrm{r}^{2}=0.97\right)$ in the second year (Figure 1). A linear increase was observed in dry matter yields with increasing plant water consumptions (ETa). A linear relationship was also reported in previous studies between corn grain yield and evapotranspiration (Payero et al. 2006, Overman and Martin 2002). Yolcu and Cetin (2015) confirmed the linear relationships between grain and silage yield response to irrigation for corn. On the other hand, Kiziloglu et al. (2009) indicated that the decrease in fresh biomass yield per unit decrease in irrigation water was not constant.

The relationships between plant water consumption (ETa) and kernel yields may also be assessed through the relationships between relative reduction in water consumption and relative reduction in yield (Gencoglan and Yazar, 1999). Water-yield relationships were used to assess the relationships between relative reduction in evapotranspiration and relative reduction in yield and adjusted maximum yield values corresponding to maximum evapotranspiration values were determined. Then, for (1-Eta $\mathrm{ET}^{-1}$ ) and adjusted yield values, (1-Ya $\left.\mathrm{Ym}^{-1}\right)$ ratios were determined. Linear regression analyses were performed in experimental years between (1-Eta ET $\left.{ }^{1}\right)$ and $\left(1-\mathrm{Ya} \mathrm{Ym}^{-1}\right)$ and equations were developed for the entire growth season. The yield response factor (ky) was determined as 0.74 for the overall growth season of the first year as 1.06 in the second year (Figure 2).

Average ky value of two years was calculated as 0.97 . When the experimental years were assessed together, it was observed that amount of irrigation water applied to irrigation treatments were different (Table 3). Therefore, plant water consumptions and fresh biomass yields were also different. Then, different ky values were observed in experimental years. It can be stated that irrigation treatments had a significant effect on ky values. Yield respond factor $(\mathrm{ky})$ is a quite significant parameter for irrigation planning and used as a measure of the effects of water deficits throughout growing season on crop yield. Gencoglan and Yazar (1999) reported ky values as between 1.61-1.08; Özgürel and Pamuk (2003) reported the lowest ky value as 0.90 and the greatest value as 1.07 ; Kuscu (2010) reported the seasonal ky value as 0.90 ; Simsek and Gercek (2005) as beween 0.70-0.97; Dagdelen et al. (2006) as 1.04; Oktem (2006) as between 0.88-0.93; Kaman (2007) as between 0.75-1.78. Ertek and Kanber (2000) reported ky value as 0.70 and indicated that a unit water deficit may result in 0.70 unit decrease in yield. The present ky values were different from some of the above mentioned authors and were similar to some others. Slight differences were because of the differences in climate parameters, plant water consumptions, cultivars, soil characteristics and irrigation programs.

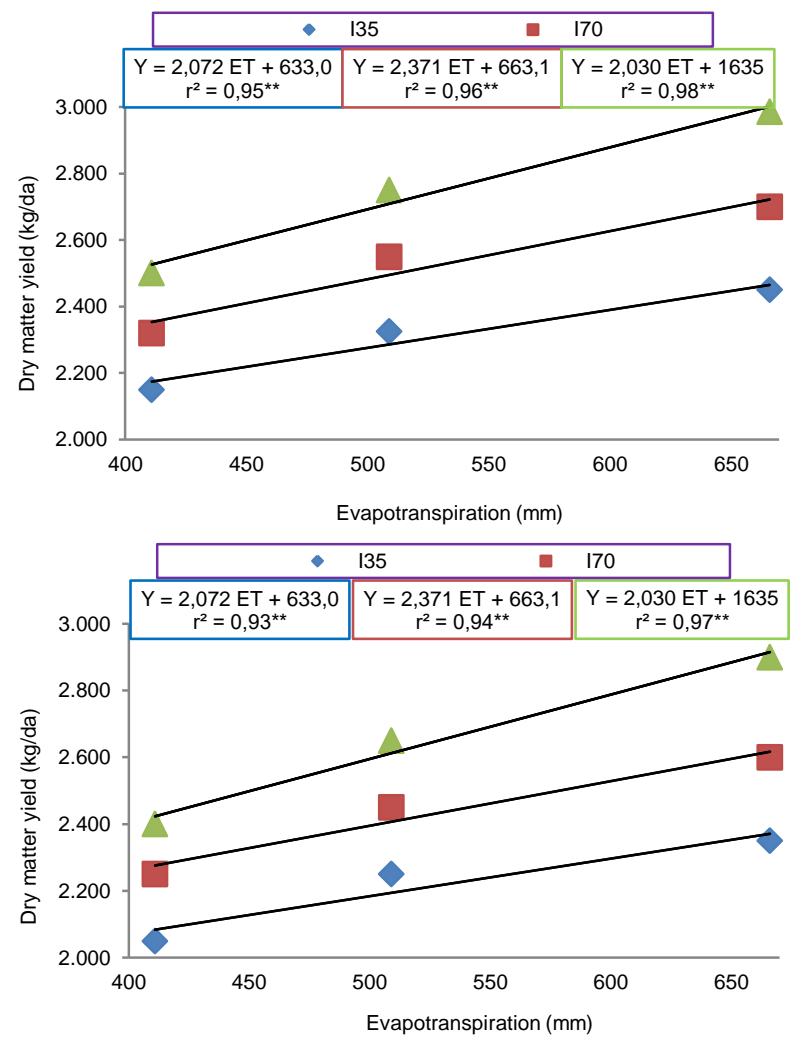

Figure 1 Plant water consumption - dry matter yield relationships of irrigation treatments

Water use efficiency (WUE) values indicating kernel yield in response to seasonal plant water consumption are provided in Table 3 for different irrigation treatments. WUE values varied with irrigation treatments. In experimental years, the lowest WUE value was observed in $\mathrm{I}_{35}$ irrigation treatment respectively with 3.65 and 3.62 $\mathrm{kg} \mathrm{da}{ }^{-1} \mathrm{~mm}$ and the highest value was observed in $\mathrm{I}_{100}$ treatment respectively with 4.42 and $4.38 \mathrm{~kg} \mathrm{da}^{-1} \mathrm{~mm}$. WUE values of the other irrigation treatments were between these values. WUE values were quite close to each other. Except for $\mathrm{I}_{35}$ irrigation treatment, there are slight differences between WUE values of treatments. Since applied irrigation water quantities, water consumptions and dry matter yields were close to each other, similar WUE values were observed. These slight differences were mainly because of similar water deficits applied throughout the growing season. There was an increasing trend in WUE values with increasing water consumptions $\left(\mathrm{I}_{100}\right)$. This could be explained that dry matter (DM) accumulation was increased by irrigation (Kiziloglu et al. 2009). Similarly, Dagdelen et al. (2006) reported increasing WUE values with increasing applied irrigation quantities. WUE values were reported as between 1.49 - $2.71 \mathrm{~kg} \mathrm{~m}^{-3}$ by Ozgurel and Pamuk (2003), between $8.84-11.0 \mathrm{~kg} \mathrm{~m}^{-3}$ by Mostafa and Derbala (2013), between $19.56-29.52 \mathrm{~kg} \mathrm{~m}^{-3}$ by Ariturk and Erdem ( 2011), between $2.0-2.9 \mathrm{~kg} \mathrm{~m}^{-3}$ by Trejo et al. (2006) and between $1.74-2.61 \mathrm{~kg} / \mathrm{m}^{3}$ by Kuscu (2010). Kiziloglu et al. (2009) reported the greatest water use efficiency as $15.04 \mathrm{~kg} \mathrm{~m}^{-3}$ in full irrigation and the lowest value as 3.16 $\mathrm{kg} \mathrm{m}^{-3}$ in non-irrigated treatment. While current findings were similar to findings of Kiziloglu et al. (2009), they were higher than the findings of Trejo et al. (2006), 
Ozgürel and Pamuk (2003) and Kuscu (2010) and lower than the values reported by Mostafa and Derbala (2013) and Ariturk and Erdem (2011). Such differences were again because of differences in plant species, local climate conditions, plant densities, irrigation programs and cultural practices. However, while dry matter yields were taken into consideration when calculating WUE values in this study, fresh biomass yields were taken into consideration in above mentioned studies. Therefore, the values were not complying one another. Mostafa and Derbala (2013) and Bouazzama et al. (2012) reported decreasing WUE values in maize with decreasing irrigations. Gencoglan and Yazar (1999), Zhang et al. (2004) and Dagdelen et al. (2006) reported the lowest WUE values for corn in non-irrigated conditions. Current WUE values comply with these earlier findings.

The lowest irrigation water use efficiency (IWUE) value of two years was observed in $\mathrm{I}_{35}$ irrigation treatment with $3.81 \mathrm{~kg} \mathrm{da}^{-1} \mathrm{~mm}$ and the highest value was observed in $\mathrm{I}_{70}$ irrigation treatment with $5.05 \mathrm{~kg} \mathrm{da}^{-1} \mathrm{~mm}$. Decreasing IWUE values were observed with increasing irrigation water quantities. Current findings comply with the results of Gencoglan and Yazar (1999) indicating similar decreasing trends in IWUE values with increasing applied irrigation water.

\section{Fresh Biomass (FB)}

Fresh biomass (FB) harvest was performed at dough stage with a black line between kernel and cob (Bouazzama et al. 2012). There were significant differences in fresh biomass yields of irrigation treatments $(\mathrm{P}<0.01)$. For the first and second year of the experiments, the lowest FB yield was obtained from $\mathrm{I}_{35}$ irrigation treatment $\left(63.40 \mathrm{t} \mathrm{ha}^{-1}\right)$ and the greatest value was obtained from $\mathrm{I}_{100}$ irrigation treatment $\left(106.25 \mathrm{t} \mathrm{ha}^{-1}\right)$. Plant canopy developed more, number of leaves increased and thus fresh biomass yields linearly increased with increasing applied irrigation water quantities. However, genotype is another significant factor effecting fresh biomass yields of the cultivars. Kiziloglu et al. (2009) reported fresh biomass yield under Erzurum conditions as between 50.74-80.70 t ha-1, Erdal et al. (2009) reported the yields under Antalya conditions as between 54.61$76.54 \mathrm{t} \mathrm{ha}^{-1}$ and Yolcu and Cetin (2015) reported the values under semi-arid climate conditions as between 54.8-93.3 $\mathrm{t} \mathrm{ha}^{-1}$. Current findings were higher than the values reported by Kiziloglu et al. ( 2009) and Erdal et al. (2009), but relatively similar with the ones reported by Yolcu and Cetin (2015). Such differences were primarily because of differences in irrigation programs and methods, soil and climate conditions, genetic diversity, ripening durations and cultural practices.

1-(Eta/Etm) (2014)

- 1-(Eta/Etm) (2015)

Figure 2The relationship between evapotranspiration reduction and relative yield reduction

Table 4 Correlation coefficients between fresh biomass quality parameters

\begin{tabular}{|c|c|c|c|c|c|c|}
\hline Year (2014) & Dry Matter & Protein Content & $\mathrm{ADF}$ & NDF & ETa & $\mathrm{FB} * * *$ \\
\hline Dry Matter & 1.0000 & & & & & \\
\hline Protein Content & $0.6703 * *$ & 1.0000 & & & & \\
\hline $\mathrm{ADF}$ & $0.1872 \mathrm{~ns}$ & $-0.2580 \mathrm{~ns}$ & 1.0000 & & & \\
\hline NDF & $-0.0077 \mathrm{~ns}$ & $-0.4207 n s$ & $0.9800 * *$ & 1.0000 & & \\
\hline ETa & $0.7824 * *$ & $0.8752 * *$ & $0.1280 \mathrm{~ns}$ & $-0.0449 \mathrm{~ns}$ & 1.0000 & \\
\hline $\mathrm{FB}$ & $0.7923^{* *}$ & $0.9334 * *$ & $0.0114 \mathrm{~ns}$ & $-0.1664 n s$ & $0.9885 * *$ & 1.0000 \\
\hline Year (2015) & Dry Matter & Protein Content & $\mathrm{ADF}$ & NDF & ETa & FB \\
\hline Dry Matter & 1.0000 & & & & & \\
\hline Protein Content & $0.6698 * *$ & 1.0000 & & & & \\
\hline $\mathrm{ADF}$ & $0.5688 * *$ & $0.3843^{*}$ & 1.0000 & & & \\
\hline NDF & $0.6603^{* *}$ & $0.2844^{\mathrm{ns}}$ & $0.9024 * *$ & 1.0000 & & \\
\hline ETa & $0.8135^{* *}$ & $0.8087 * *$ & $0.2450^{\mathrm{ns}}$ & $0.2976^{\mathrm{ns}}$ & 1.0000 & \\
\hline FB & $0.4117^{*}$ & $0.3827 *$ & $-0.1212^{\mathrm{ns}}$ & $-0.1003^{\mathrm{ns}}$ & $0.7392 * *$ & 1.0000 \\
\hline
\end{tabular}

ADF: Acid Detergent Fiber, NDF: Neutral Detergent Fiber, FB: Fresh biomass, ETa: Plant water consumption, $* *$ : significant at P<0.01, ns: Not significant, *** Particularly emphasized parts are taken into consideration. Therefore, the others are not emphasized. 
It can be stated that fresh biomass yield in maize was closely related to applied irrigation water quantities. There was an increasing trend in full irrigation and decreasing trend in deficit irrigation treatments. When the irrigation water requirement was supplied fully, plant leaves fully developed and leaf ratio was higher than stalk ratio (Frost et al., 2008). As it was in the other forage crops, differences in fresh biomass yields of irrigation treatments were because of differences in applied irrigation water quantities. Yolcu and Cetin (2015) in a deficit irrigation study on silage maize indicated different FB values and reported the lowest value for excessive water deficit treatment. Similar differences in fresh biomass yields of irrigation treatments were also reported by other researchers (Kiziloglu et al. 2009; Bouazzama et al. 2012).

\section{Quality Analyses Results}

In the first year, the greatest crude protein ratio was observed in $\mathrm{I}_{100}$ treatment with $8.62 \%$ and the lowest crude protein ratio was observed in $\mathrm{I}_{35}$ treatment with $7.17 \%$. During the second year, the greatest crude protein ratio was observed in $\mathrm{I}_{100}$ treatment with $7.53 \%$ and the lowest crude protein ratio was observed in $\mathrm{I}_{35}$ treatment with $7.19 \%$. Sufficient moisture levels within plant root zone and thus potential transpiration and photosynthesis of leaves yielded optimum crude protein ratios in full irrigation treatment $\left(\mathrm{I}_{100}\right)$ (Leakey et al., 2006). A portion of organic matter produced through photosynthesis, the most basic metabolism of the plants, is used in production of protein-specific precursory materials. These processes take place in chloroplasts. With the aid of DNA, RNA and ribosomes in stroma, chloroplasts both produce the proteins required for their activities and complement itself. Thus, for full activity of chloroplasts, optimum moisture is supplied with full irrigation $\left(\mathrm{I}_{100}\right)$. When the irrigation water requirement was fully supplied, organic matter is synthesized in Calvin cycle initiated with carbon dioxide fixation. A portion of synthesized organic matter is used in structure of glycerol, fatty acids, vitamins, proteins and amino acids. In this sense, optimum photosynthesis reaction takes place when the irrigation water requirement of the plant was fully supplied $\left(\mathrm{I}_{100}\right)$. With the degradation of synthesized organic matters in peroxisomes, protein precursors are formed. Such a case then assumed to increase protein ratios in full irrigation $\left(\mathrm{I}_{100}\right)$ ( Lawlor and Tezara, 2009).

Karasahin and Sade (2011) reported protein ratios in drip irrigation as between $8.31-8.75 \%$, Buyukerdem and Akman (2008) reported protein ratios with zincsupplemented fertilizers as between $10.7-11.4 \%$, Ariturk and Erdem (2011) reported protein ratios as between 8.13-8.94\% and Yolcu and Cetin (2015) reported the values as between $7.40-8.80 \%$. While current findings were relatively similar with the results reported by Karasahin and Sade (2011) and Yolcu and Cetin (2015), they were lower than the values reported by Buyukerdem and Akman (2008), Ariturk and Erdem (2011). Such differences were mainly because of differences in soil and climate conditions, irrigation program and methods, cultural practices and supplementary micro fertilizer $(\mathrm{Zn})$ treatments.
Variance analyses revealed that there were not significant differences in ADF (Acid Detergent Fiber) and NDF (Neutral Detergent Fiber) values of irrigation treatments. Current findings comply with the results of Isik et al (2012) indicating linear increases in crude protein ratios with increasing irrigation water levels and insignificant differences in $\mathrm{ADF}$ and $\mathrm{NDF}$ ratios of different irrigation levels.

Several researchers indicated that a quality maize fresh biomass should have a digestible dry matter (DDM) content of $70-75 \%$ and animals could convert that much DDM into optimum yields (Karakozak and Ayasan 2010; Guney et al., 2010). Therefore, the digestible dry matter content of $70 \%$ in $\mathrm{I}_{100}$ irrigation treatment complied with the values specified for quality silage. The DDM content of $68 \%$ in $\mathrm{I}_{35}$ irrigation treatment indicated that DDM ratios decreased linearly with increasing water deficits and DDM contents negatively influenced by water deficits. High DDM ratio of full irrigation treatment $\left(\mathrm{I}_{100}\right)$ may also be related to low $\mathrm{ADF}$ ratio (25\%) of the treatment. In brief, DDM ratios increased with decreasing $\mathrm{ADF}$ ratios. Higher ADF ratios of deficit irrigation treatments also decreased DDM ratios in these treatments.

Correlation analyses were performed to elucidate the relationships between plant water consumption and quality parameters of maize. The correlation coefficients (r) for the relationships of plant water consumption (ETa) with protein ratio, ADF, NDF and silage yield are provided in Table 4. There were some significant correlations between investigated traits at $1 \%$ level. Highly positive correlation (r: 0. 824) was observed between ETa and dry matter content of the first year $(\mathrm{P}<0.05)$. The greatest correlation ( $\mathrm{r}$ : 0.98) was observed between ETa and fresh biomass yield. The correlation coefficient between ETa and protein content was identified as (r: 0.87) and significant positive correlation was observed between ETa and protein content at $1 \%$ level.

In the second year, highly positive correlation (r: 0.8135 ) was observed between ETa and dry matter at $1 \%$ significance level. The correlation coefficient between ETa and protein content was observed as (r: 0.87 and the correlation was again significantly positive at $1 \%$ level. The correlations of ETa with ADF and NDF were not found to be significant. Therefore, it can be stated based on these findings that dry matter and protein contents linearly increased with increasing plant water consumptions. Then, it can also be stated that deficit irrigations should be avoided for quality silage. However, $\mathrm{I}_{70}$ deficit irrigation can also be recommended under deficit water resources conditions. Previous researchers also reported positive correlations between plant water consumption and dry matter contents (Camoglu et al., 2011; Kiziloglu et al., 2009; Yolcu and Cetin, 2015; Bouazzama, 2012; Karimi et al., 2005; Demirtas and Kirnak, 2009). Karasahin and Sade (2011) reported similar correlations between plant water consumption and protein contents. Thus, current findings comply with those earlier results. 


\section{Conclusion}

Current findings revealed that total fresh and dry matter yield of silage maize significantly decreased with water stress. Water use efficiency values decreased with increasing water deficit levels. A positive linear relationship was observed between evapotranspiration and total fresh biomass yield. Digestible dry matter (DDM) and leaf area index values also increased with increasing amount of applied irrigation water.

Correlation analyses revealed significant correlations between plant water consumption (ETa) and quality parameters at $1 \%$ significance level. Highly positive correlation was observed between ETa and dry matter (r: 0.80) $(\mathrm{P}<0.01)$. The correlation coefficient between ETa and protein content was identified as (r: 0.80) and the positive correlation was also assessed as highly significant at $1 \%$ level. Dry matter and protein contents linearly increased with increasing plant water consumptions. On the other hand, water use efficiency (WUE) values were quite different in different irrigation treatments. The lowest WUE values of the experimental years were observed in $\mathrm{I}_{35}$ irrigation treatments respectively with 3.65 and $3.62 \mathrm{~kg} \mathrm{da}^{-1} \mathrm{~mm}$ and the greatest values were observed in $\mathrm{I}_{100}$ irrigation treatment respectively with 4.42 and $4.38 \mathrm{~kg} \mathrm{da}^{-1} \mathrm{~mm}$.

Dry matter yields decreased by $22 \%$ under $30 \%$ deficit $(158 \mathrm{~mm})$ and decreased by $56.2 \%$ under $65 \%$ (353.5 $\mathrm{mm})$ deficits. Statistical analysis revealed that $I_{100}$ irrigation treatment with $33 \mathrm{t} \mathrm{ha}^{-1}$ dry biomass yield was placed in the $1^{\text {st }}$ group and the $I_{70}$ irrigation treatment with $25.5 \mathrm{t} \mathrm{ha}^{-1}$ dry biomass yield was placed in the $2^{\text {nd }}$ group (they were placed in quite close groups). Therefore, it was thought that production with more than $30 \%$ water deficit was not profitable and such higher deficit ratios significantly reduce dry biomass yields and quality of the resultant silage. Thus it was concluded that full irrigation $\left(\mathrm{I}_{100}\right)$ should be applied in maize culture under semi-arid climate conditions when the water resources were sufficient. However, under deficit water resources in semi-arid climates, $\mathrm{I}_{70}$ irrigation treatment can be recommended. When the deficit irrigations were distributed evenly over the growing stages, the yield response factor $(\mathrm{ky})$ indicating the effects of water deficits on crop yields can be taken as 0.90 .

\section{Acknowledgements}

The present study was supported by Scientific Research Projects Department of Siirt University (SIUZIR-08).

\section{References}

Ali T, Anwar S, Shah WA, Ahmad B. 2004. Response of maize hybrids /cultivars to various levels of potassium and irrigation frequencies. Journal Agron 3(3): 201- 207.

Alkhamisi SA, Abdelrahman HA, Ahmed M, Goosen MFA. 2011. Assessment of reclaimed water irrigation on growth, yield and water-use efficiency of forage crops. Applied Water Science 1(1, 2): 57-65.

Ariturk ME, Erdem Y. 2011. Determination of irrigation scheduling and water yield quality relationship of second crop maize (Zea mays l.), ADU Faculty Journal of Agriculture 8 (1): $73-82$.
Ayasan T, Karakozak E. 2012. Effect of quality and nutrient in silage inoculants resulting from the use of different forage crops. Firat University Journal of Health Sciences 26 (2): 93-98.

Blake GR, Hartge KH. 1986. Bulk density. In: Methods of Soil Analysis, Part 1, Physical and Mineralogical Methods. (ed: A. Klute) Agr. Monogr. 9. ASA and SSSA, Madison WI. P. 363-375

Bouazzama B, Xanthoulis D, Bouaziz A, Ruelle P, Mailhol JC. 2012. Effect of water stress on growth, water consumption and yield of silage maize under flood irrigation in a semiarid climate of Tadla (Morocco). Biotechnologie, Agronomie, Société et Environment 16 (4): 468-477.

Bouyoucos GJ. 1962. Hydrometer method improved for making particle size analyses of soils. Agronomy J 54(5): 464-465.

Budak F, Budak F. 2014. Quality on forage plants and factors effecting forage quality. Turkish Scientific Collection Journal 7 (1): 01-06.

Buyukerdem NI, Akman Z. 2008. Effects of different zinc containing fertilizers applications on ear yield and some agronomic and quality characters of sweet corn. Journal of Plant and Environmental Scence 1: 21-27.

Camoglu G, Genc L, Asik S. 2011. The effects of water stress on physiological and morphological parameters of sweet corn (zeamays saccharata sturt.). Ege University Faculty of Agriculture Journal 48 (2): 141-149. Aydın/Turkey.

Carpici EB, Celik N, Bayram G. 2010. Yield and quality of forage maize as influenced by plant density and nitrogen rate. Turkish Journal of Field Crops 15(2): 128-132.

Cui N, Du T, Kang S, Li F, Zhang J, Wang M, Li Z. 2008. Regulated deficit irrigation. Agric Water Manage 95: 489497.

Dagdelen N, Yilmaz E, Sezgin F, Gurbuz T. 2006. Water-yield relation and water use efficiency of cotton (Gossypium hirsutum L.) and second crop corn (Zea mays L.) in western Turkey. Agric Water Manage 82: 63-85.

Danielson RE, Sutherland PL. 1986. Porosity. in: Methods of soil Analysis, Part 1, Physical and Mineralogical Methods. (ed: A. Klute) Agr. Monogr. 9. ASA and SSSA, Madison WI. P. 443-461.

Demirtas MN, Kirnak H. 2009. Effects of different irrigation systems and intervals on physiological parameters in apricot. YYU J Agr Sci 19(2): 79-83.

Dengiz O, Saglam M, Ozaytekin HH, Baskan O. 2013. Weathering rates and some physico-chemical characteristics of soils developed on a calcic to posequences. Carpathian Journal of Earth and Environmental Sciences 8(2): 13-24.

Doorenbos J, Kassam AH. 1979. Yield response to water. FAO 33, Rome.

DMI. 2016.Meteorological statistics. Turkish State Meteorological Service. Available at www.dmi.gov.tr (Accessed: 10 April 2016)

El-Gizawy NKB, Slaem HM. 2010. Influence of nitrogen sources on yield and its components of some maize varieties. World Journal of Agricultural Science 6(2): 218223.

El-Hendawy SE, Schmidhalter U. 2010. Optimal coupling combinations betweenirrigation frequency and rate for dripirrigated maize grown on sandy soil. Agricultural Water Management 97: 439-448.

El-Hosary AAA. 2015. Genetic analysis of water stress tolerance attributes in F1 maize diallel crosses. J Plant Breed 19(6): 1765-1781.

Erdal S, Pamukçu M, Ekiz H, Soysal M, Savur O, Toros A. 2009. The determination of yield and quality traits of some candidate silage maize hybrids. Akdeniz University Faculty of Agriculture Journal 22 (1): 75-81.

Ertek A, Kanber R. 2000. Water-use efficiency (WUE) and change in the yield-response factor (Ky) of cotton irrigated by an irrigation drip system. Turkish Journal of Agriculture and Foresty 25 (2): 111-118. 
Filya I. 2002. Silage making. forage plant breeding and forage production. Harvest Publishing, Kayseri, 59-86.

Frost RA, Wilson LM, Launchbaugh KL, Hovde EM. 2008. Seasonal change in forage value of rangeland weeds in Northern Idaho. Invasive Plant Science and Management 1(4): $343-351$

Gencoglan C, Yazar A. 1999. The effects of deficit irrigations on corn yield and water use efficiency. Turk Journal Agric Forest 23: 233-241.

Geren H, Kavut YT. 2009. An investigation on comparison of Sorghum (Sorghum sp.) species with corn (Zea mays L.) grown under second crop production. Ege University Faculty of Agriculture Journal 46 (1): 9-16.

Gheysari M, Mirlatifi SM, Homaee M, Asadi ME, Hoogenboom G. 2009. Nitrate leaching in a silage maize field under different irrigation and nitrogen fertilizer rates. Agricultural Water Management 96: 946-954.

Greenwood KL, Mundy GN, Kelly KB. 2008. On-farm measurement of the water use and productivity of maize. Aust Journal Exp Agric 48(3): 274-284.

Guney E, Tan M, Gul ZD, Gul I. 2010. Determination of yield and silage quality of some maize cultivars in Erzurum Conditions. Ataturk University Faculty Journal of Agriculture 41(2): 105-111

Hammad HM, Ahmad A, Abbas F, Farhad W. 2012. Optimizing water and nitrogen use for maize production under semiarid conditions. Turk Journal Agric For 36: 519-532.

Howell TA, Musick JT. 1985. Relationship of dry matter production of field crops to water consumption. Proc Int Con On Crop Water Requirements Paris. 11-14.September.

Howell TA. 2001. Enhancing water use efficiency in irrigated agriculture. Agron Journal. 93: 281-289.

Howell TA. 2006. Challenges in increasing water use efficiency in irrigated agriculture. The Proceedings of International Symposium on Water and Land Management For Sustainable Irrigated Agriculture. April 4-8, 2006, Adana, Turkey.

Igbadun HE, Salim BA, Tarimo AKPR, Mahoo HF. 2008. Effect of deficit irrigation scheduling on yields and soil water balance of irrigated maize. Irrigation Science, 27: 1123.

Isik S, Aydogan S, Gunes A, Ozcan G, Tezel M, Aksoyak S, Aktas AH, Mulayim A, Tamkoc A, Acar R, Tari AF, Ates S. 2012. Artificial pasture determining the impact on quality of irrigation level. Research Journal of Agricultural Sciences 5(2): 148-150.

Kacar B, Inal A. 2008. Chemical analysis of plant and soil. II . Plant analysis. Ankara University Agriculture Faculty Publication $453 \mathrm{p}$.

Kaman H. 2007. Yield response of maize genotypes to conventional deficit irrigation and partial root drying. Cukurova University Department of Agricultural Structures and Irrigation Institute of Natural and Applied Science Unıversity of Çukurova Ph. D. Thesis, 102p. Adana.

Karakozak E, Ayasan T. 2010. Fleig scores of different forage and silage made in the use of inoculants and mix effects on raw food. Kafkas Univ Vet Fak Journal 16 (6): 987-994.

Karasahin M, Sade B. 2011. Effects of different irrigation methods on grain yield and yield components of hybrid maize (zea mays 1. indentata s.). Journal of Agricultural Faculty of Uludag University 25(2): 47-56.

Karimi Y, Prasher SO, McNairn H, Bonnell RB, Dutilleul P, Goel PK. 2005. Discriminant analysis of hyperspectral data for assessing water and nitrogen stresses in corn. Trans. of the ASAE 48(2): 805-813.

Kang S, Zhang J. 2004. Controlled alternate partial root-zone irrigation: its pysiological consequences and impact on water use efficiency. Journal of Experimental Botany 55: 2437-2446.
Kassam AH, Molden D, Fereres E, Doorenbos J. 2007. Water productivity: Science and practice-introduction. Irr Sci 25: 185-188.

Katerji N, Hoorn JW, Hamdy A, Karam F, Mastrorilli M. 1996. Effect of salinity on water stress, growth and yield of maize and sunflower, Agricultural Water Management 30: 237-249.

Kirda C. 2002. Deficit irrigation scheduling based on plant growth stages showing water stress tolerance. Deficit irrigation practice. Water Rep 22. FAO, Rome, pp.3-10.

Kiziloglu MF, Sahin U, Kuslu T. 2009. Determining water-yield relationship, water use effîciency, crop and pan coeffients for silage maize in a semiarid region. Irrigation Science 27: 129-137.

Klute A. 1986. Water retention: In: Klute, A. (Ed.), Methods of Soil Analysis. Part 2, Physical and Mineralogical Methods, 2nd Edition, Agronomy Monograph No.9, Soil Science Society of America, Madison, WI. pp. 635-653.

Kuscu H. 2010. Corn grown in Bursa deficit conditions yield and quality effects of irrigation. Uludag University Institute of Science and Agricultural Structures and Irrigation Department, PhD Thesis, 103 p. Bursa.

Kuscu H, Turhan A, Demir AO. 2014. The response of processing tomato to deficit irrigation at various phenological stages in a sub-humid environment. Agricultural Water Management, 133: 92-103.

Lawlor DW, Tezara W. 2009. Causes of decreased photosynthetic rate and metabolic capacity in waterdeficient leaf cells: a critical evaluation of mechanisms and integration of processes. Annals of botany 103(4): 561-579.

Leakey AD, Uribelarrea M, Ainsworth EA, Naidu SL, Rogers A, Ort DR, Long SP. 2006. Photosynthesis, productivity, and yield of maize are not affected by open-air elevation of $\mathrm{CO} 2$ concentration in the absence of drought. Plant Physiology 140(2): 779-790.

Li Y, Cohen Y, Wallach R, Cohen S, Fuchs M. 2005. On quantifying soil water deficit of a partially wetted root zone by the response of canopy or leaf conductance. Agr Water Management 65: 21-38.

Mostafa H, Derbala A. 2013. Performance of supplementary irrigation systems for corn silage in the sub-humid areas. Agricultural Engineering International: The CIGR Journal of Scientific Research and Development. 15(4): 9-15.

Nehring K. 1960. Agricultur chemis cheunter suchungs method enfürdünge-und futter mittel böden und milch. Hamburg und Berlin: Verlang Paul Parey.

Nelson DW, Sommers LE. 1996. Total carbon, organic carbon, and organic matter. In: Sparks, D.L.(Ed.). Methods of Soil Analysis. Chemical Methods. American Society of Agronomy, Madison, WI, Pp: 961-1010.

Norwood CA, Dumler TJ. 2002. Transition to dry land agriculture: Limited irrigated vs. dry land corn. Agronomy Journal 94: 310-320.

Overman AR, Martin FG. 2002. Corn response to irrigation and tillage. Commun Soil Sci Plant Anal 33(19-20): 3603-3608.

Ozgurel M, Pamuk G. 2003. Corn water-yield relationships and ceres-maize plant growth evaluation of the conformity of the model a study on regional policy. TARP-2340. Izmir.

Oktem A. 2006. Effect of different irrigation intervals to drip irrigated dent corn (Zea mays L.indentata) water-yield relationship. Pakistan Journal of Biological Sciences 9(8): 1476-1481.

Pandey RK, Maranville JW, Chetima MM. 2000. Deficit irrigation and nitrogen effects on maize in a sahelian environment II. shoot growth, nitrogen uptake and water extraction. Agr Water Manage 46: 15- 27.

Payero JO, Tarkalson DD, Irmak S, Davison D, Petersen JL. 2009. Effect of timing of a deficit-irrigation allocation on corn evapotranspiration, yield, water use efficiency and dry mass. Agricultural Water Management 96: 1387-1397. 
Payero JO, Melvin SR, Irmak S, Tarkalson D. 2006. Yield response of corn to deficit irrigation in a semiarid climate. Agr Water Manage 84(1-2): 101-112.

Perez-Pastor A, Domingo R, Torrecillas A, Ma C Ruiz-Sanchez. 2009. Response of apricot trees to deficit irrigation strategies. Irrigation Sci 27(3): 231-242.

Sammis TW. 1981. Yield of alfalfa and cotton as influenced by irrigation. Irrigation Agron Journal 73(2): 323-329.

Savoie P, Amyot A, Theriault R. 2002. Effect of moisture content, chopping and processing on silage effluent. Transactions of the ASAE 45 (4): 907-914.

Scott HD. 2000. Soil-plant-water relations. Soil physics. Agricultural and environmental applications. Iowa State University, 2121 South State Avenue, Ames, Iowa, pp 322 355.

Simsek M, Gercek S. 2005. The effect of different irrigation interval on water-yield relationship of corn (Zea Mays L. indentata) grown in semi-arid conditions. Ataturk University Faculty Journal of Agriculture 41(2): 105-111

Smith D, Dijak M, Bulman P, Ma B, Hamel C. 1999. Barley: physiology of yield. In: Crop Yield. Springer, pp 67-107.

Stewart DW, Dwyer LW. 1999. Mathematical characterization of leaf shape and area of maize hybrids. Crop Sci, 39: 422427.

Trejo JAM, Monsivais GA, Ramirez OJ, Gozzalez ZA, Cerda RE, Hernandez FM, Sosa SE, Nuncio AR. 2006. Effect of three driptape installation depths on water use efficiency and yield parameters in forage maize (zea mays 1.) cultivation. Tec Pecu Mex 44 (3): 359-364.

TUIK. 2014. Statistics of crop production. Available at www.tuik.gov.tr (Accessed: 08 March 2014).
Tuzuner A. 1990. Soil and water analysis laboratory, T.C. Ministry of Agriculture, Forestry and Rural Affairs, General Directorate of Rural Services, Ankara.

Ucak AB, Gencoglan C, Degirmenci H. 2013. The effect of direct and traditional seeding methods and different water levels on the water-yield relationship of drip irrigated corn. JFAE 11(3\&4): 828-833.

Umar UU, Ado SG, Aba DA, Bugaje SM. 2014. Estimates of combining ability and gene action in maize (Zea mays L.) under water stress and non-stress conditions. Journal of Biology, Agriculture and Healthcare 4 (25): 247-253.

Van Soest PJ, Robertson JB, Lewis BA. 1991. Methods for dietary fiber, neutral detergent fiber, and nonstarch polysaccharides in relation to animal nutrition. Journal Dairy Science 74: 3583-3597.

Yolcu R, Cetin O. 2015. Nitrogen fertigation to improve nitrogen use efficiency and crude protein on silage corn. Turkish Journal of Field Crops 20 (2): 233-241.

Yoshida S. 1983. Rice. In: W.H. Smith and S.J. Banta (Editors), Potential Productivity of Field Crops under Different Environments. International Rice Research Institute,Los Bafios, Philippines, pp. 103-128.

Zeleke KT, Wade LJ. 2012. Evapotranspiration estimation using soil water balance, weather and crop data. pp. 41b58. In Irmak, A. (ed). Evapotranspiration Remote Sensing and Modeling. In Tech Europe, Rijeka, Croatia.

Zhang Y, Kendy E, Qiang Y, Changming L, Yanjun S, Hongyong S. 2004. Effect of soil water deficit on evapotranspiration, crop yield, and water use efficiency in the north China plain. Agric Water Manage 64: 107-122. 